\title{
GYDYTOJŲ PSICHOSOCIALINIAI DARBO APLINKOS VEIKSNIAI IR JŲ SĄSAJOS SU GYVENIMO KOKYBE
}

\author{
Rasa Žutautienė, Ričardas Radišauskas, Rūta Ustinavičienė, \\ Jolita Kirvaitienė, Kornelija Rakutytè \\ Lietuvos sveikatos mokslu universiteto Medicinos akademijos Visuomenès sveikatos fakultetas
}

Raktažodžiai: gydytojų sveikata, psichosocialinè aplinka, stresas, perdegimas darbe.

\begin{abstract}
Santrauka
Psichosocialinis veiksnys - tai aplinkybė, veiksmas, situacija, kuri turi itakos darbuotojo fizinei sveikatai, drauge sukeldama jam stresą [1]. Tyrimo tikslas buvo nustatyti pagrindinius gydytojų psichosocialinius darbo aplinkos veiksnius ir jų sąsajas su gyvenimo kokybe. $2018 \mathrm{~m}$. kovo - vasario mèn. anoniminès apklausos būdu, naudojant standartizuotus klausimynus, atlikta vienmomentinè epidemiologinè Raseinių, Jonavos, Kaišiadorių, Kèdainių ir Prienų ligoninėse dirbančių gydytojų apklausa. Tyrimo imtis $-\mathrm{n}=230$ respondentų (atsako dažnis 79,4 proc.). Nustatyta, kad 41,3 proc. (n=95) respondentų reikia didelių specifinių ịgūdžių darbe, penktadalis $(n=44)$ teigè, kad darbo reikalavimai yra dideli ir tik pusė respondentų $(\mathrm{n}=126)$ manè, kad sprendimų prièmimo laisvè yra vidutinè. Nustatyta reikšminga priklausomybè tarp amžiaus ir darbui specifinių ịgūdžiu poreikio, darbo reikalavimų ir bendradarbių paramos. Beveik pusè (48,7 proc.) gydytojų patyre vidutini elgsenos stresą. Perdegimas darbe atsirado dèl per didelio darbo krūvio, kontrolès ir informacijos stokos, socialinio palaikymo trūkumo. Gydytojų subjektyvios sveikatos prognozei reikšmingą vertę turèjo psichologinis stresas (elgsenos, somatinis, kognityvinis), profesinis perdegimas ir darbui specifinių igūdžiu poreikis.
\end{abstract}

\section{Ivadas}

PSO sveikatą apibūdina kaip fizinę, psichinę bei socialinę gerovę, o ne vien ligos ar negalios nebuvimą. Tai yra holistinis požiūris ị sveikatą, kuris nepripažįsta vieno konkretaus aspekto, nulemiančio žmogaus sveikatą. PSO duomenimis, vienas didžiausių dabartinių iššūkių yra darbuotojų sveikatos gerinimas ir organizacijų psichosocialinių darbo aplinkos veiksnių valdymas [2]. Gausu mokslinių publikacijų, kuriose tiriama slaugytojų darbo aplinka, tačiau vis dar trūksta tyrimų apie gydytojų psichosocialinę darbo aplinką, rizikos veiksnius ir jų itaką gydytojų sveikatai bei darbo kokybei.

Psichosocialinis veiksnys - veiksnys, kuris dèl darbo sąlygų, darbo reikalavimų, darbo organizavimo, darbo turinio, darbuotojų tarpusavio ar darbdavio ir darbuotojo tarpusavio santykių sukelia darbuotojui stresą [3]. Mokslinėse publikacijose teigiama, kad gydytojų psichosocialinès darbo sąlygos tiesiogiai ir netiesiogiai daro įtaką sveikatos priežiūros kokybei. Psichosocialinę riziką didina aukšti darbo reikalavimai ir kontrolè, emocinis išsekimas, autonomijos stoka, darbo nesaugumas, etiniai konfliktai ir prasti socialiniai santykiai [1].

Higienos instituto duomenimis, Lietuvoje dirba daugiau nei 45000 įvairių sveikatos priežiūros specialybių darbuotojų, iš kurių 12887 yra gydytojai [4]. Gydytojas kasdien susiduria su bloga psichosocialine aplinka: sunkiais sprendimais, dilemomis, dideliu krūviu, neadekvačiu atlygiu už darbą, dažnu vadovų ar bendradarbių nepalaikymu. Pervargusiems arba nepatenkintiems savo darbu gydytojams padideja profesiniu klaidų tikimybè, atsiranda sveikatos problemų [5].

Tyrẻjai yra nustatę, kad ilgalaikè ekspozicija stresinėje aplinkoje gali sukelti perdegimo sindromą [6].

Gydytojų psichosocialinių veiksnių bei streso įvertinimas leidžia ịsigilinti ị problemą, suprasti jos mastą, priežastis bei viso proceso pasekmes ne tik gydytojui, bet ir mūsų visuomenei [7].

Darbo tikslas - nustatyti pagrindinius gydytojų psichosocialinius darbo aplinkos veiksnius ir jų sąsajas su gyvenimo kokybe.

\section{Tyrimo medžiaga ir metodai}

Siekiant įvertinti gydytojų psichosocialinius darbo aplinkos veiksnius ir jų sąsajas su gyvenimo kokybe buvo atliktas vienmomentinis epidemiologinis tyrimas, kuris vyko $2018 \mathrm{~m}$. 
kovo - vasario mėnesiais. Tyrimui atlikti buvo gautas Kauno regioninio biomedicinių tyrimų etikos komiteto leidimas Nr. BE-2-41. Tyrime dalyvavo Kauno regiono ligoninèse (Kèdainių, Kaišiadorių, Prienų, Jonavos, Raseinių) dirbantys gydytojai. Respondentai buvo supažindinti su darbo tikslu ir uždaviniais, buvo garantuotas informacijos anonimiškumas. Respondentai anketas pildè savo darbo vietose. Išdalinta 340 anketų (sveikatos priežiūros įstaigų duomenimis, iš viso jose dirbo $(\mathrm{N}=340)$ gydytojų), iš jų grąžinta 270 (atsako dažnis 79,4 proc.). Tinkamai užpildyta buvo 230 anketų, jos panaudotos statistinei duomenų analizei. Tyrime dalyvavo 166 ( 72,2 proc.) vyrai ir 64 ( 27,8 proc.) moterys. Jauniausiam respondentui buvo 24 metai, o vyriausiam - 80 metų. Tiriamųjų amžiaus vidur-

1 lentelè. Tyrimo dalyvių charakteristikos ( $\mathrm{N}$, proc.).

\begin{tabular}{|c|c|c|c|}
\hline \multicolumn{2}{|c|}{ Charakteristika } & \multirow{2}{*}{$\frac{\mathbf{N}}{166}$} & \multirow{2}{*}{$\begin{array}{c}\text { Proc. } \\
72,2\end{array}$} \\
\hline \multirow{2}{*}{ Lytis } & Vyras & & \\
\hline & Moteris & 64 & 27,8 \\
\hline \multirow{3}{*}{ Amžius } & $<40 \mathrm{~m}$. & 85 & 37,0 \\
\hline & $41-50 \mathrm{~m}$. & 38 & 16,5 \\
\hline & $>50 \mathrm{~m}$ & 107 & 46,5 \\
\hline \multirow{4}{*}{$\begin{array}{l}\text { Šeiminè } \\
\text { padètis }\end{array}$} & $\begin{array}{l}\text { Nevedęs (netekè- } \\
\text { jusi) }\end{array}$ & 43 & 18,7 \\
\hline & Vedęs (ištekėjusi) & 144 & 62,6 \\
\hline & Išsiskyręs (-usi) & 31 & 13,5 \\
\hline & Našlys (-è) & 12 & 5,2 \\
\hline \multirow{3}{*}{$\begin{array}{l}\text { Vaikų } \\
\text { skaičius }\end{array}$} & Neturi vaikų & 61 & 26,8 \\
\hline & Turi 1 vaiką & 55 & 24,1 \\
\hline & Turi 2 ir daugiau & 112 & 49,1 \\
\hline \multirow{3}{*}{ Darbo stažas } & $<11 \mathrm{~m}$ & 77 & 33,5 \\
\hline & $11-30 \mathrm{~m}$. & 89 & 38,7 \\
\hline & $>30 \mathrm{~m}$ & 64 & 27,8 \\
\hline \multirow{4}{*}{$\begin{array}{l}\text { Darbo sritis/ } \\
\text { sektorius }\end{array}$} & Chirurginis & 50 & 21,7 \\
\hline & Terapinis & 121 & 52,6 \\
\hline & $\begin{array}{l}\text { Akušerijos-gine- } \\
\text { kologijos }\end{array}$ & 16 & 7,0 \\
\hline & Kita & 43 & 18,7 \\
\hline \multirow{4}{*}{$\begin{array}{l}\text { Darbo } \\
\text { krūvis }\end{array}$} & $<0,5$ etato & 10 & 4,3 \\
\hline & $0,5-1$ etato & 38 & 16,5 \\
\hline & $>1-1,5$ etato & 136 & 59,1 \\
\hline & $>1,5$ & 46 & 20,1 \\
\hline \multirow{2}{*}{ Pareigos } & Gydytojas & 193 & 83,9 \\
\hline & Rezidentas & 37 & 16,1 \\
\hline
\end{tabular}

kis buvo $47,17 \pm 13,17$ metų. Tiriamujų demografinès charakteristikos pateiktos 1 lentelèje.

Tyrimo instrumentas. Tyrimo anketa buvo sudaryta iš 5 dalių. Pirmoji dalis klausimų atskleidè respondentų demografines charakteristikas. Antroji anketos dalis - Kopenhagos perdegimo klausimynas (angl. Copenhagen Burnout Inventory). Sis klausimynas yra suskirstytas ị tris dalis: asmeninį perdegimą, asmens perdegimą dèl darbinès veiklos, asmens perdegimą, susijusi su darbu ir pacientais. Tiriamųju atsakymai buvo vertinami 5 balų skale: visada, dažnai, kartais, retai, niekada/beveik niekada. Vadovaujantis klausimyno autorių metodika, atsakymų variantai buvo perversti ị balų sistemą 0-100 (visada 100, dažnai 75 , kartais 50 , retai 25 , niekada/beveik niekada 0 ). Kiekvienos skalès ịvertinimą atitiko paskaičiuotas skalès balų vidurkis. Trečioji anketos dalis - standartizuotas "Pasitenkinimo darbu klausimynas" (angl. Job Content Questionnare) skirtas psichosocialinei darbo aplinkai vertinti. Ketvirtosios dalies - SF-36 (angl. Short Form 36 Medical Outcomes Study Questionnaire), klausimais buvo siekiama sužinoti gydytojų subjektyvią sveikatos būklę. Pagal šị klausimyną buvo vertinamos 8 subskalès: fizinè būklè, veiklos apribojimas dẻl fizinių sutrikimų, kūno skausmai, bendra sveikatos būklè, energingumas, socialinis funkcionavimas, veiklos apribojimas dẻl emocinių sutrikimų ir psichiné būklè. Didžiausia galima balų suma - 100. Kuo balų daugiau - tuo geresnè gyvenimo kokybė. Šiuo klausimynu buvo vertinama respondentų pastarujų keturių savaičių savijauta. Atsakymai yra vertinami balais ir pagal tam tikrą algoritmą apskaičiuojama kiekviena sritis. Penktoji dalis - Kopenhagos psichosocialinio klausimyno 3 skalès (angl. Copenhagen Psychosocial Questionnaire). Klausimais siekiama įvertinti gydytojų patiriamą stresą darbo aplinkoje (elgsenos, somatinis, kognityvinis). Visi klausimai turejjo penkis atsakymų variantus (visada, dažnai, kartais, retai, niekada, beveik niekada arba visiškai sutinku, sutinku, iš dalies sutinku, beveik nesutinku, visiškai nesutinku) [8]. Vadovaujantis klausimyno autorių metodika atsakymų variantai buvo perversti ị balų sistemą 0-100 (visada 100, dažnai 75 , kartais 50, retai 25, niekada/beveik niekada 0). Kiekvienos

1 pav. Tiriamųjų psichosocialinių darbo aplinkos veiksnių pasiskirstymas priklausomai nuo jų lygio.

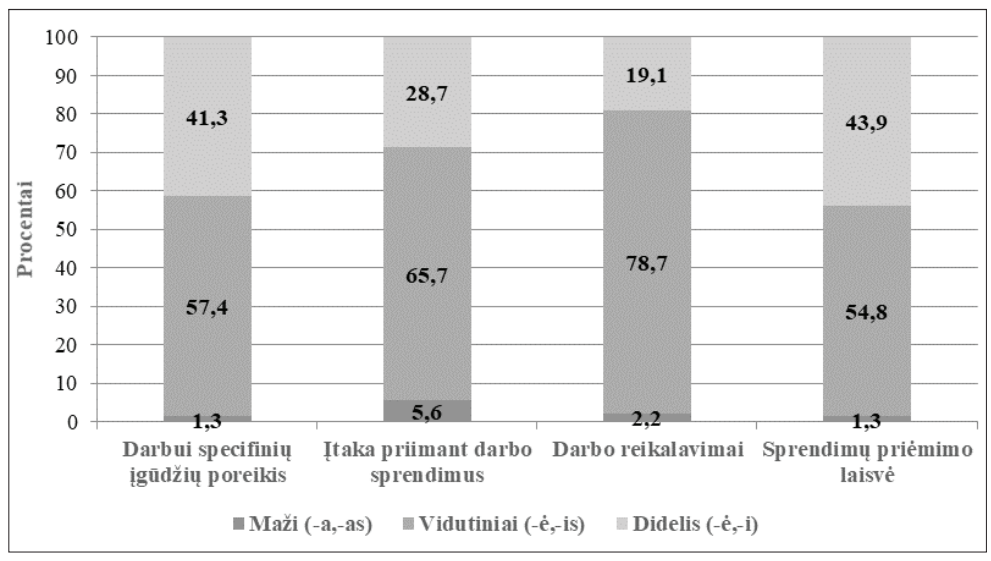


skalès įvertinimą atitiko paskaičiuotas skalès balų vidurkis. Jis suskirstytas atsižvelgiant ị tercilių ribas - aukštas (100-66,7), vidutinis $(66,6-33,3)$ ar žemas $(33,2-0)$ stebimo reiškinio lygis.

Statistinė analizė. Statistinè duomenų analizė atlikta naudojantis statistiniu programiniu duomenų paketu SPSS 20.0 for Windows. Gautų kintamųjų ịvertinimui buvo naudojami aprašomosios statistikos metodai, duomenys pateikiami procentais, vidurkiais ir standartiniais nuokrypiais. Hipotezės apie požymių priklausomybę tikrintos taikant chi kvadrato $\left(\chi^{2}\right)$ ir z kriterijus. Statistiškai reikšmingiems skirtumams buvo taikytas Mano Vitney (Mann-Whitney) (U) arba Kruskalio Voliso (Kruskal-Wallis) kriterijus ir jo p reikšmė. Ryšiams tarp požymių nustatyti buvo naudojamas Spirmeno (Spearmen) koreliacija, daugianarè tiesinè regresija, kuria buvo siekiama nustatyti sąsajas tarp psichosociali-

2 lentelè. Psichosocialinių darbo aplinkos veiksnių ryšys su sociodemografiniais ir darbo organizavimo veiksniais.

$r$-Spirmeno korel. koeficientas, $p$ - reikšmingumas, $*_{-}<0,05$, ** $-<0,01$

\begin{tabular}{|l|l|l|l|l|l|}
\hline Veiksniai & & Amžius & Vaikų skaičius & Darbo stažas & Darbo krūvis \\
\hline $\begin{array}{l}\text { Darbui specifinių } \\
\text { igūdžių poreikis }\end{array}$ & $\mathrm{r}$ & $-0,161^{*}$ & $-0,070$ & 0,006 & $-0,143^{*}$ \\
\cline { 2 - 6 } & $\mathrm{p}$ & 0,014 & 0,291 & 0,924 & 0,030 \\
\hline $\begin{array}{l}\text { Itaka priimant } \\
\text { darbo sprendimus }\end{array}$ & $\mathrm{r}$ & 0,115 & 0,057 & $-0,034$ & 0,124 \\
\cline { 2 - 6 } & $\mathrm{p}$ & 0,081 & 0,392 & 0,610 & 0,061 \\
\hline \multirow{2}{*}{ Darbo reikalavimai } & $\mathrm{r}$ & $-0,151^{*}$ & $-0,158^{*}$ & $0,245^{* *}$ & $-0,101$ \\
\cline { 2 - 6 } & $\mathrm{p}$ & 0,022 & 0,017 & 0,000 & 0,128 \\
\hline $\begin{array}{l}\text { Sprendimų priè- } \\
\text { mimo laisvé }\end{array}$ & $\mathrm{r}$ & 0,002 & 0,013 & $-0,025$ & 0,016 \\
\cline { 2 - 6 } & $\mathrm{p}$ & 0,978 & 0,846 & 0,708 & 0,812 \\
\hline \multirow{2}{*}{$\begin{array}{l}\text { Bendradarbių } \\
\text { parama }\end{array}$} & $\mathrm{r}$ & $-0,202^{* *}$ & 0,000 & 0,013 & $-0,186^{* *}$ \\
\cline { 2 - 6 } & $\mathrm{p}$ & 0,002 & 0,999 & 0,848 & 0,005 \\
\hline \multirow{2}{*}{ Vadovo parama } & $\mathrm{r}$ & $-0,104$ & $-0,123$ & $-0,118$ & $-0,119$ \\
\cline { 2 - 6 } & $\mathrm{p}$ & 0,117 & 0,064 & 0,075 & 0,072 \\
\hline
\end{tabular}

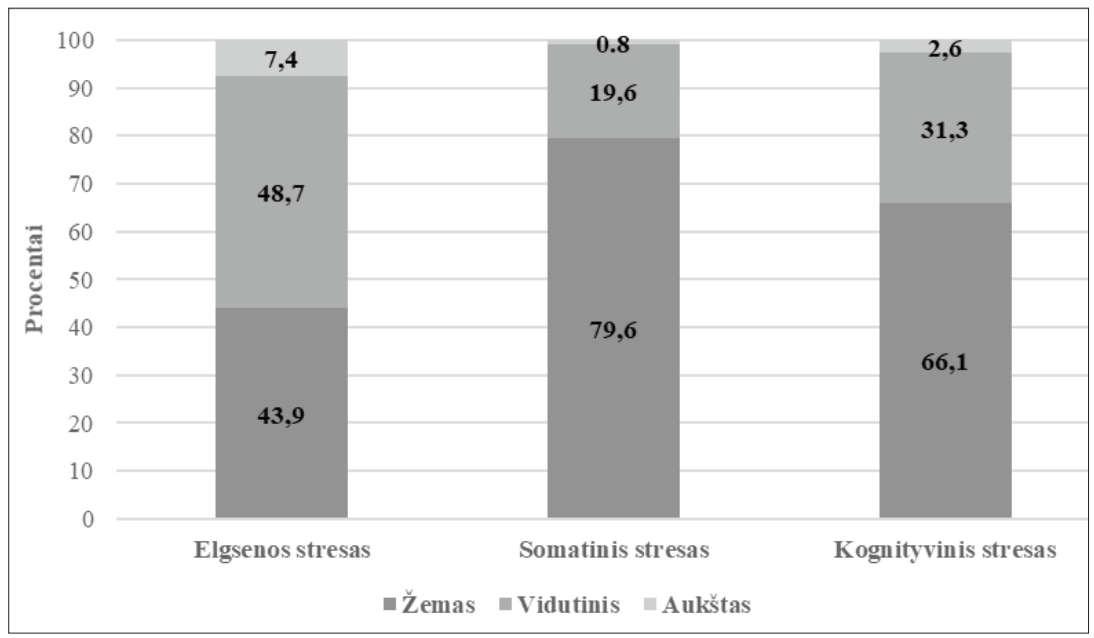

2 pav. Tiriamujų pasiskirstymas pagal streso tipą ir lygị. nės darbo aplinkos ir gyvenimo kokybės. Skirtumas tarp požymių buvo laikomas statistiškai reikšmingu, kai $\mathrm{p}<0,05$.

\section{Rezultatai}

Darbdaviai, vadovai ir darbuotojai bendradarbiaudami organizacijoje gali išspręsti streso ir psichosocialinès rizikos darbe problemas, todèl darbe buvo vertinami šie psichosocialiniai darbo aplinkos veiksniai: darbo reikalavimai, itaka priimant darbo sprendimus, darbui specifinių ịgūdžių poreikis, sprendimų priemimo laisvè, bendradarbių ir vadovo parama.

Beveik pusè $(41,3$ proc.) $(\mathrm{n}=95)$ respondentų nurodè, kad darbe reikia didelių specifinių ịūdžių. Beveik penktadaliui $(19,1$ proc.) $(n=44)$ respondentų atrodè, kad darbo reikalavimai yra dideli ir tik pusè $(54,8$ proc.) $(\mathrm{n}=126)$ respondentų manè, kad sprendimų prièmimo laisvė yra vidutinè (1 paveikslas).

Nustatyta reikšminga priklausomybė tarp amžiaus ir darbui specifinių igūdžių poreikio, darbo reikalavimų ir bendradarbių paramos $(\mathrm{p}<0,05)$. Svarbu paminèti, kad kuo gydytojų darbo stažas buvo didesnis, tuo darbo reikalavimai buvo aukštesni, ir taip pat nustatyta, kad kuo darbo krūvis buvo didesnis, tuo mažesnè bendradarbių parama (2 lentelè).

İvertinę skirtingų streso išraiškų pasireiškimo lygius nustateme, kad vidutini elgsenos stresą patyrè pusè (48,7 proc.) gydytojų, žemą somatinį stresą jaute didžioji dalis ( 79,6 proc.) respondentų. Vidutinị kognityvinị stresą patyre trečdalis (31,3 proc.) respondentu (2 paveikslas).

Bendrą profesini perdegimą patyré kas trečias apklaustas gydytojas $(32,2$ proc.). Nagrinėjant perdegimo lygi darbe nustatyta, kad perdegimas darbe buvo reikšmingai susijęs su subjektyvia sveikata. Bendrą profesini perdegimą sąlygojo: fizinè veikla, veiklos apribojimas dèl fizinių sutrikimų, kūno skausmai, bendra sveikatos būklè, energingumas, socialinis funkcionavimas, veiklos apribojimas dèl emocinių sutrikimų, psichinè 
būklè ir gyvenimo kokybė. Analizuojant ryšio stiprumus nustatyta, kad stipriausiai asmeninis perdegimas ir darbo su pacientais sukeltas perdegimas susijęs su energingumu ir psichine būkle (3 lentelè).

Pasitenkinimas darbu siejosi su psichosocialiniais veiksniais, atlikta daugialypė regresiné analizè. Tyrème kaip gydytoju gyvenimo kokybę veikia penki aspektai: profesinis perdegimas, somatinis, kognityvinis, elgsenos stresas ir darbui specifinių ịgūdžių poreikis. Sudarant regresijos modeli, priklausomu kintamuoju pasirinkta subjektyvi sveikata, nepriklausomais - psichosocialiniai veiksniai. Regresijos modelis, prognozuojant tiriamujų subjektyvią sveikatą paaiškino 46,6 proc. sklaidos. Buvo nustatyta, kad gydytojų subjektyvios sveikatos prognozei statistiškai reikšmingą vertę turëjo psichologinis stresas (elgsenos, somatinis, kognityvinis stresas), profesinis perdegimas ir darbui specifinių ịūdžių poreikis. Elgsenos bei somatinis stresas didesniu laipsniu lèmé blogesnę gydytojų gyvenimo kokybę. Kiti psichosocialiniai veiksniai, tokie kaip bendrasis perdegimas ir kognityvinis stresas, mažesniu laipsniu lèmẻ blogesnę gydytojų gyvenimo kokybę. Nustatyta, kad didelis darbo specifinių igūdžių poreikis lèmé geresnę gyvenimo kokybę (4 lentelè).

\section{Rezultatų aptarimas}

Lietuvoje dirbantys gydytojai, kaip ir kitų šalių gydytojai, kiekvieną dieną darbe susiduria su psichosocialiniais darbo aplinkos veiksniais. PSO duomenimis, vienas didžiausių dabartinių iššūkių yra darbuotojų sveikatos gerinimas ir organizacijų psichosocialinių darbo aplinkos veiksnių valdymas [2]. Atlikus gydytojų apklausą paaiškejjo, kad iš gydytojų reikalaujama daug specifinių igūdžių (41,3 proc.), beveik penktadalis (19,1 proc.) mano, kad darbo reikalavimai yra per dideli ir tik pusè $(54,8$ proc.) turi didelę sprendimų prièmimo laisvę. Gauti tyrimo rezultatai parodè, kad labiausiai tirtoje darbuotojų grupeje pasireiške šie psichosocialiniai darbo aplinkos veiksniai: maža įtaka priimant darbo sprendimus, dideli reikalavimai darbe bei maža vadovo ar bendradarbių parama. Kitose šalyse taip pat gauti panašūs rezultatai. Dauguma Serbijos ligoninėse dirbančių gydytojų dirbo neigiamoje psichosocialinèje darbo aplinkoje, jiems buvo keliami dideli reikalavimai ir jie turejjo per mažai autonomijos [9]. Vokietijoje vykdytame psichosocialinių darbo aplinkos veiksnių tyrime buvo siekiama nustatyti, ar depresijai vystytis turi įtakos darbo aplinka. Išvados parodè, kad rezidentų depresijos riziką mažino pakankama autonomija darbe ir parama [10]. Lietuvoje dirbantys gydytojai vis dar turi per mažai autonomijos, dèl kurios gali atsirasti nepakankama motyvacija dirbti, nenoras dalyvauti sveikatos apsaugos reformos procesuose, taip pat galimi klinikinių sprendimų laisvès suvaržymai, kurie gali turèti ịtakos sveikatos priežiūros paslaugų kokybei [11].

Nustatyta, kad gydytojai darbe dažnai patiria stresą, o jis dažnai patiriamas dèl nesutarimų su pacientais, bendradarbiais, vadovais. Dažnas stresas gali sukelti neigiamus simptomus, tokius kaip: miego sutrikimai, padidejęs dirglumas, apatija, nuotaikų kaita. Gydytojams keliami reikalavimai vis didèja, nes jie turi nuolat domėtis medicinos naujovėmis bei tobulinti savo žinias. Aukštą streso lygị skatina nuolat besikeičiančios gydytojo darbo sąlygos. Mūsų atliktame tyrime elgsenos stresą patyré beveik pusė respondentų (48,7 proc.). M. Weigl ir A.Schneider teigimu, Vokietijoje net 28,4 proc. gydytojų jaučia aukštą streso lygị ir emocini išsekimą darbo aplinkoje [12]. Von dem Knesebeck taip pat teigia, kad gydytojai darbo metu

3 lentelè. Perdegimo darbe ryšys su atskirais gyvenimo kokybės aspektais (koreliacinè analizè). $r$-Spirmeno korel. koeficientas, $p$ - reikšmingumas, *-<0,05; ** - <0,01

\begin{tabular}{|c|c|c|c|c|c|c|c|c|}
\hline \multirow[t]{2}{*}{ Kintamieji } & \multicolumn{2}{|c|}{$\begin{array}{l}\text { Asmeninis } \\
\text { perdegimas }\end{array}$} & \multicolumn{2}{|c|}{$\begin{array}{c}\text { Darbo sukeltas } \\
\text { perdegimas }\end{array}$} & \multicolumn{2}{|c|}{$\begin{array}{l}\text { Darbo su paci- } \\
\text { entais sukeltas } \\
\text { perdegimas }\end{array}$} & \multicolumn{2}{|c|}{$\begin{array}{l}\text { Bendras profesi- } \\
\text { nis perdegimas }\end{array}$} \\
\hline & $\mathbf{r}$ & $\mathbf{p}$ & $\mathbf{r}$ & $\mathbf{p}$ & $\mathbf{r}$ & $\mathbf{p}$ & $\mathbf{r}$ & $\mathbf{p}$ \\
\hline Fizinė būklè & $-0,176^{* *}$ & 0,007 & $-0,119$ & 0,072 & $-0,165^{*}$ & 0,012 & $-0,169^{*}$ & 0,010 \\
\hline $\begin{array}{l}\text { Veiklos apribojimas } \\
\text { dèl fizinių sutrikimų }\end{array}$ & $-0,238 * *$ & $<0,001$ & $-0,186^{* *}$ & 0,005 & $-0,140^{*}$ & 0,034 & $-0,204 * *$ & 0,002 \\
\hline Kūno skausmai & $-0,282 * *$ & $<0,001$ & $-0,185^{* *}$ & 0,005 & $-0,183 * *$ & 0,005 & $-0,238 * *$ & $<0,001$ \\
\hline $\begin{array}{l}\text { Bendra sveikatos } \\
\text { būklè }\end{array}$ & $-0,405 * *$ & $<0,001$ & $-0,284 * *$ & $<0,001$ & $-0,285 * *$ & $<0,001$ & $-0,358 * *$ & $<0,001$ \\
\hline Energingumas & $-0,550 * *$ & $<0,001$ & $-0,469 * *$ & $<0,001$ & $-0,427 * *$ & $<0,001$ & $-0,543 * *$ & $<0,001$ \\
\hline $\begin{array}{l}\text { Socialinis funkcio- } \\
\text { navimas }\end{array}$ & $-0,412 * *$ & $<0,001$ & $-0,308 * *$ & $<0,001$ & $-0,384 * *$ & $<0,001$ & $-0,417 * *$ & $<0,001$ \\
\hline $\begin{array}{l}\text { Veiklos apriboji- } \\
\text { mas dèl emocinių } \\
\text { sutrikimų }\end{array}$ & $-0,304 * *$ & $<0,001$ & $-0,175^{* *}$ & 0,008 & $-0,199 * *$ & 0,002 & $-0,272 * *$ & $<0,001$ \\
\hline Psichinè būklè & $-0,442 * *$ & $<0,001$ & $-0,403 * *$ & $<0,001$ & $-0,462 * *$ & $<0,001$ & $-0,503^{* *}$ & $<0,001$ \\
\hline Gyvenimo kokybė & $-0,515 * *$ & $<0,001$ & $-0,390 * *$ & 0,000 & $-0,410 * *$ & $<0,001$ & $-0,496 * *$ & $<0,001$ \\
\hline
\end{tabular}


jaučia stresą, 22 proc. susiduria su neigiama psichosocialine aplinka dèl darbo reikalavimų ir kontrolès [13]. Be to, patiriamas stresas darbe turi ryši su asmenine ar šeimos aplinka. H.A.Chatta nustatė: kad didžioji dauguma (90 proc.) gydytojų manè, kad stresas yra susijęs ne tik su darbu, bet ir su šeima, pareigomis jose ir asmeniniais konfliktais [14].

Gydytojai savo profesijoje patiria ne tik stresą, bet ir profesinị perdegimą. Perdegimas turi poveikį tiek gydytojams, tiek pacientams, tiek visai sveikatos priežiūros sistemai. Teigiama, kad gydytojams, kuriems pasireiškia perdegimas darbe, didejja klaidų tikimybè. Mūsų tyrimo metu nustatyta, kad bendrą perdegimą patyrè net kas trečias gydytojas. Lietuvoje kelių tyrejjų duomenimis, net 42,3 proc. gydytojų anesteziologų-reanimatologų buvo nustatytas perdegimo sindromas [15]. Panašūs rezultatai gauti ir kitose šalyse: 12 Europos šalių vykdytame tyrime nustatyta, kad net 43 proc. gydytojų turejjo aukštą perdegimo lygi [16], Lenkijoje gydytojams nustatytas vidutinio arba aukšto lygio perdegimo sindromas [17], Vokietijoje atliktoje metaanalizejje buvo nustatyta, kad trečdalis (35,7 proc.) visų specialybių gydytojų patyrė profesini perdegimą darbo aplinkoje [18]. JAV gydytojai patyrè mažesni emocinį išsekimą nei jų kolegos Europoje [19].

Mokslinių tyrimų, kurie analizuoja subjektyvią gydytojų sveikatą, nèra daug. Tačiau mūsų tirtų gydytojų subjektyvios sveikatos vertinimas parodè, kad jų sveikata yra gera ir gyvenimo kokybe yra pakankamai aukšta. Nustatyta, kad psichosocialinè darbo aplinka lėmé gydytojų sveikatą. Esant per dideliam darbo krūviui pastebimi respondentų emociniai sutrikimai, kurie gali sukelti neigiamus tarpasmeninius santykius, nuotaikos svyravimus, nuovargi, perdegimo sindromą. C.H Croxson teigimu, Anglijoje gydytojų per didelis darbo krūvis veikia fizinę ir psichinę sveikatą, darbo ir gyvenimo kokybę bei sukelia nepasitenkinimą darbu [20]. Slovėnijos mokslininkų atliktame tyrime nustatyta, kad gydytojų populiacijoje yra reikšmingas ryšys tarp darbo krūvio ir emocinio išsekimo [21]. Londone vykusioje Karališkosios medici-

4 lentelè. Profesinio perdegimo, streso ir darbui specifinių ịgūdžių ryšys su gyvenimo kokybe (tiesinè regresinè analizè).

$R 2=0,466, F=38,863, p<0,001$

\begin{tabular}{|l|c|c|c|c|c|}
\hline \multirow{2}{*}{ Veiksniai } & \multicolumn{2}{|c|}{$\begin{array}{c}\text { Nestandartizuoti } \\
\text { koeficientai }\end{array}$} & $\begin{array}{c}\text { Standartizuoti } \\
\text { koeficientai }\end{array}$ & \multirow{2}{*}{ t reikšmé } & p reikšmé \\
\cline { 2 - 5 } & $\mathrm{B}$ & $\begin{array}{c}\text { Standartinè } \\
\text { paklaida }\end{array}$ & Beta $(\beta)$ & & \\
\hline (Konstanta) & 77,098 & 6,685 & & 11,533 & 0,000 \\
\hline Bendras profesinis perdegimas & $-0,170$ & 0,056 & $-0,190$ & $-3,058$ & 0,003 \\
\hline Elgsenos stresas & $-0,157$ & 0,042 & $-0,242$ & $-3,720$ & 0,000 \\
\hline Somatinis stresas & $-0,212$ & 0,048 & $-0,254$ & $-4,376$ & 0,000 \\
\hline Kognityvinis stresas & $-0,101$ & 0,045 & $-0,135$ & $-2,223$ & 0,027 \\
\hline Darbui specifinių igūdžių poreikis & 0,442 & 0,165 & 0,138 & 2,687 & 0,008 \\
\hline
\end{tabular}

nos draugijos konferencijoje buvo kalbama, kaip aktualu išsaugoti gydytojų sveikatą. Poilsis naktinio budejjimo metu pagerintų pacientų saugumą, dirbančiujų psichinę sveikatą, sumažintų nelaimingus atsitikimus, o gydytojai taptų laimingesni ir labiau patenkinti savo darbo aplinka [22].

Darbo sąlygos apima: darbo aplinką, darbo reikalavimus, sprendimų priemimo laisvę, bendradarbių paramą, visa tai turi tiesioginę įtaką darbingumui, saugumui ir suteikiamų paslaugų kokybei. Darbas, kuriame keliami pernelyg dideli reikalavimai ir yra maža socialinè parama, gali paveikti tiek fizinę, tiek psichinę gydytojų sveikatą. Vis daugėja įrodymų, kad yra ryšys tarp streso, depresijos, psichikos sveikatos problemų ir darbo aplinkos. Mūsų tyrime buvo nustatytos sąsajos tarp gydytojų gyvenimo kokybès ir psichologinio streso, profesinio perdegimo ir darbui specifinių ịgūdžių poreikio. $2019 \mathrm{~m}$. Olandijos mokslininkai nustatè, kad gydytojai pediatrai darbo vietoje patiria aukšto lygio stresą ir tai turi ịtakos jų emocinei būsenai. Tėvų agresija ir nepasitenkinimas pediatrų atliktu darbu yra gana dažna problema jų veikloje, kuri sukuria ịtampą ir nerimą [23]. S. Kumar teigia, kad perdegimas padidina depresijos riziką, nerimą, miego sutrikimus, nuovargi, piktnaudžiavimą alkoholiu ir narkotikais. Pastebèta, kad gydytojai, kurie dirba neigiamoje psichosocialinejje darbo aplinkoje, anksčiau išeina ị pensiją ir yra linkę i savižudybes [24]. Tarp Jungtinèje Karalystėje dirbančiu gydytojų psichinių ligų paplitimas svyruoja nuo 17 iki 52 proc., perdegimas nuo - 31 iki 54,3 proc., depersonalizacija nuo 17,4 iki 44,5 proc. Visi šie sutrikimai ir ligos siejamos su nepasitenkinimu savo darbo vieta, ilgomis darbo valandomis. Straipsnio autoriai pabréžia, kad suprastėjusi gydytojų sveikata gali tureti įtakos sveikatos priežiūros paslaugų teikimui [25].

Mūsų ir kitų autorių atliktuose tyrimuose stebint psichosocialinius darbo aplinkos veiksnius pastebimas gydytojų aukštas streso ir perdegimo lygis, kurị sukelia dideli darbo reikalavimai, per maža vadovų parama, maža autonomijos laisvè. Psichosocialinè aplinka daro neigiamą įtaką darbuotojų sveikatai. Pritaikius psichosocialinių darbo aplinkos veiksnių rizikos valdymo modelị sumažètų streso ir perdegimo darbe rizika.

\section{Išvados}

Nustatyta, kad beveik pusei apklaustų gydytojų darbe reikia daug specifinių ịgūdžių, beveik penktadaliui keliami darbo reikalavimai yra dideli ir tik pusė respondentų sprendimų prièmimo laisvę įvardija kaip vidutinę. Ivertinus skirtingų streso išraiškų pasireiškimo 
lygius nustatyta, kad pusès gydytojų elgsenos streso lygis yra vidutinis, o daugumos somatinio ir kognityvinio - žemas. Rezultatai atskleide reikšmingą somatinio streso ryši su amžiumi ir darbo stažu.

Rezultatų analizè parodè, kad bendras profesinis perdegimas gydytojų darbe reikšmingai siejosi su fizine būkle, veiklos apribojimais dèl fizinių sutrikimų, kūno skausmais, bendra sveikatos būkle, sumažějusiu energingumu, veiklos apribojimu dèl emocinių sutrikimų, psichine būkle ir gyvenimo kokybe. Gydytojų darbo vietoje patiriamas stresas buvo susijęs su blogesne gyvenimo kokybe. Nustatyta, kad gydytojų gyvenimo kokybès prognozei reikšmingą vertę turèjo psichologinis stresas (elgsenos, somatinis, kognityvinis), profesinis perdegimas ir darbui specifinių igūdžių poreikis.

\section{Literatūra}

1. Macleod J, Davey Smith G. Psychosocial factors and public health: a suitable case for treatment? J Epidemiol Community Health 2003; 57:565-570.

https://doi.org/10.1136/jech.57.8.565

2. World Health organization, Work organisation and stress, No 3 Work organizations \& stress, 2005. https://www.who.int/ occupational_health/publications/pwh3rev.pdf?fbclid=IwAR 134w_32O3mLU1JOUsxOvekdHv797fmPfoeUjUz1eKidrV 1RGv8zUQEhZ0

3. Dèl Lietuvos Respublikos socialinès apsaugos ir darbo ministro ir Lietuvos Respublikos sveikatos apsaugos ministro 2012m. spalio 25d. įsakymo. Nr. A1-457/V-961 "Dèl profesinės rizikos vertinimo bendrujų nuostatų patvirtinimo". https:/www.vdi. 1t/AtmUploads/PsichosocialiniaiRizikosVeiksniaiStresoDarbeVertinimoRekomendacijos.pdf

4. Lietuvos gyventojų sveikata ir sveikatos priežiūros įstaigų veikla $2017 \mathrm{~m}$. Higienos institutas. http://www.hi.lt/lt/lietuvos-gyventoju-sveikata-ir-sveikatos-prieziuros-istaiguveikla2013-m.html.

5. Baba I. Workplace stress among doctors in government hospitals: an empirical study. International Journal of Multidisciplinary 2012; 2(5).

6. Dewa CS, Loong D, Bonato S, Nguyen XT, Jacobshow P: How does burnout affect physician productivity? A systematic literature review. BMC Health Services Research 2014; 14:325. https://doi.org/10.1186/1472-6963-14-325

7. Constitution of the World Health Organization. https://www. who.int/governance/eb/who_constitution_en.pdf

8. Žalnieraitienė K., Misevičienė I., Šimatonienė V., Masiliūnienė G. Ligoninejje dirbančio medicinos personalo rizika susirgti lètinėmis neinfekcinėmis ligomis ir savo sveikatos vertinimas. Visuomenès sveikata, 2011; 4(55).

9. Ilić IM, Arandjelović MŽ, Jovanović JM\&Nešić MM. Relationships of work-related psychosocial risks, stress, individual factors and burnout-Questionnaire survey among emergency physicians and nurses 2017; 68(2):167-178. https://doi.org/10.13075/mp.5893.00516

10. Weigl M, Hornung S, Petru R, Glaser J\&Angerer P. Depressive symptoms in junior doctors: a follow-up study on work-related determinants. International Archives of Occupational and Environmental Health, 2012. https://doi.org/10.1007/s00420-011-0706-8

11. Virbalis R., Gefenas E. Gydytojų profesinès autonomijos etinés problemos: Lietuvos atvejis. Visuomenès sveikata, 2012; 2(57): 16-23.

12. Weigl M, Schneider A, Hoffmann F, Angerer P. Work stress, burnout, and perceived quality of care: a cross-sectional study among hospital pediatricians. European Journal of Pediatrics 2015; 174(9):1237-46.

https://doi.org/10.1007/s00431-015-2529-1

13. Von dem Knesebeck O, Klein J, Frie KG, Blum K, Siegrist J. Psychosocial stress among hospital doctors in surgical fields: results of a nationwide survey in Germany. Deutsches Arzteblatt International 2010. https://doi.org/10.3238/arztebl.2010.0248

14. Chatta HA, Zafar A, Amin F. Measurement of stress among doctors in surgical intensive care unit (ICU) of Lahore General Hospital, Lahore. Pakistan Journal of Medical \& Health Sciences 2017; 11(3):874-877.

15. Mikalauskas A. Perdegimo sindromas tarp Lietuvos anesteziologų reanimatologų [Daktaro disertacija] 2018;55-59.

16. Soler JK, Yaman H, Esteva M, Dobbs F, Asenova RS, Katić M, Kotányi P. Burnout in European family doctors: the EGPRN study. Family Practice 2008; 25(4):245-65.

https://doi.org/10.1093/fampra/cmn038

17. Makara-Studzińska M, Załuski M, Tylec A, Panasiuk L. Do Polish doctors suffer from occupational burnout syndrome? An attempt to find an answer-Pilot study. Annals of Agricultural and Environmental Medicine 2019; 26(1):191-197.

https://doi.org/10.26444/aaem/105392

18. Rodrigues H, Cobucci R, Oliveira A, Cabral JV, Medeiros L, Gurgel K, Gonçalves AK. Burnout syndrome among medical residents: a systematic review and metaanalysis. PloS One 2018; 13(11).

https://doi.org/10.1371/journal.pone.0206840

19. Lee RT, Seo B, Hladkyj S, Lovell BL, Schwartzmann L. Correlates of physician burnout across regions and specialities: a metaanalysis. Human Resources for Health 2013; 28;11:48.

https://doi.org/10.1186/1478-4491-11-48

20. Croxson $\mathrm{CH}$, Ashdown HF, Hobbs FR. GPs' perceptions of workload in England: a qualitative interview study. Br J Gen Pract 2017; 67(655):138-147. https://doi.org/10.3399/bjgp17X688849

21. Penšek L, Selič P. Empathy and burnout in Slovenian family medicine doctors: the first presentation of Jefferson scale of empathy results. Slovenian Journal of Public Health 2018; 57(3): 155-165. 
https://doi.org/10.2478/sjph-2018-0020

22. Rimmer A. Doctors should nap during night shifts, Conference hears 2016.

https://doi.org/10.1136/bmj.i6255

23. Van Steijn ME, Scheepstra KWF, Yasar G, Olff M, de Vries MC van Pampus MG. Occupational well being in pediatricians-a survey about work related posttraumatic stress, depression, and anxiety. European Journal of Pediatrics 2019; 5: 681-693. https://doi.org/10.1007/s00431-019-03334-7

24. Kumar S. Burnout and doctors: prevalence, prevention and intervention in healthcare. Multidisciplinary Digital Publishing Institute 2016;4:37.

https://doi.org/10.3390/healthcare4030037

25. Imo UO. Burnout and psychiatric morbidity among doctors in the UK: a systematic literature review of prevalence and associated factors. BJPsych Bulletin 2017; 41(4):197-204.

https://doi.org/10.1192/pb.bp.116.054247

THE PSYCHOSOCIAL WORK ENVIRONMENT OF PHYSICIANS IN ASSOCIATION WITH THEIR QUALITY OF LIFE

\section{R.Žutautienė, R.Radišauskas, R.Ustinavičienė,} J.Kirvaitienė, K.Rakutyte்

Keywords: health of physicians, psychosocial environment, occupational stress, burnout.
Summary

Psychosocial factor - that is a condition, an action, a situation which have influence for physical health of the employee, at the same time causing stress [1]. The aim of this study was to find out the main psychosocial work environment's factors and their association for life quality of the physicians.

Using standardized questionnaires during March-February period in 2018 was carry out by using anonymous questionnaire survey among physicians in hospitals of Raseiniai, Jonava, Kaišiadoriai, Kèdainiai and Prienai. Sample size (n) was 230 respondens (response rate $79.4 \%$ ). We find out that for $41.3 \%(n=95)$ respondents are needed specific skills in their job, one fifth $(n=44)$ said are needed high work requirements, just half respondents $(n=126)$ thought that freedom of decision making is moderate.

Was found out significant relation between age and demand of work specific skills, work requirements and co-workers support. Almost half (48.7\%) of physicians experienced moderate behavioral stress. Burnout at the work arose due to overload, control, information and social support deficiency.

Correspondence to: rasa.zutautiene@1smuni.lt

Gauta 2019-06-14 